\title{
SWAT Team: A Student Leadership Club to Support Student School Connectedness and Teacher Technology Use
}

\author{
Derek Tranchina \\ Monmouth University \\ Vecihi S. Zambak \\ Monmouth University
}

\begin{abstract}
Research suggests that many school technology programs have a new, unanticipated need for ongoing training and job-embedded support for teachers and students (Sheninger \& Murray, 2017; Warschauer, 2012). Additionally, the seemingly unrelated problem of low student attachment to school is widespread (Klem \& Connell, 2004). Student technology leadership clubs, when trained and led properly, are one possible solution to both problems (Ertmer \& Hruskocy, 1999; Harper, 2008). This mixed-methods study took place at a middle grades school and blended student interviews with quantitative student achievement and attendance data, as well as teacher technology-use survey data. The study has determined that student technology leadership clubs that train students in relevant technology and empower students as leaders can enhance students' attachment to school while also improving teacher technology use.
\end{abstract}

Keywords: school technology programs, instructional technology, student leadership, student empowerment, technology integration, school belongingness, extracurriculars

\section{INTRODUCTION}

It has been proven that a student's engagement in school is a key determinant in their academic achievement (Klem \& Connell, 2004; Wang \& Holcombe, 2010). High levels of student engagement are correlated with better attendance, behavior, and overall attachment to school (Klem \& Connell, 2004). Research suggests that instructional technology, when integrated properly, can strongly enhance student engagement (Heafner, 2004; Morris \& Parker, 2014). In response, schools around the world are adopting one-to-one tablet and laptop initiatives (Henrie, Halverson, \& Graham, 2015). While many schools embrace the potential power of educational technologies, there are many new problems that have arisen from these efforts.

While many schools embrace the potential power of educational technologies, there are many new problems that have arisen from these efforts. Educational leaders argue that, whereas the intentions are good, the majority of the schools do not yet use technology in a way that benefits student learning (Harris \& Hofer, 2009; Lei \& Zhao, 2007). Recent studies acknowledge this problem and call it the digital use divide, recognizing how there is a difference between teachers and students who use technology in active, meaningful ways, versus those who use it for passive content absorption (Dolan, 2016; Warschauer, 2012). While access to technology has drastically increased over the last two decades, the support networks to 
make technology work successfully in schools (e.g., technical support staff, media specialists, teacher training) have not necessarily followed suit. The lack of support networks tends to especially exist in schools of low-socioeconomic status, where teachers face a unique set of challenges (Hudson \& Lowrey, 2016).

Furthermore, research strongly suggests that a student's attachment to school is directly correlated with their health, social well-being, and academic achievement (Blum, 2005; CDC, 2009). Unfortunately, the problem of low attachment to school is widespread (Klem \& Connell, 2004; Quin, 2017). Extracurricular clubs are one solution to the problem of low student attachment to school (Bayat, 2015; Gilman, 2001). Schools that have embraced 1:1 technology programs should consider leveraging students' strengths as digital natives by creating student technology leadership clubs. These clubs have been shown to enhance students' achievement and attachment to school while also providing much-needed support to school technology programs (Ertmer \& Hruskocy, 1999; Harper, 2008). Furthermore, the technology training that students received as members of the club provided an essential foundation for success, improving their abilities to complete school assignments and boosting their confidence to help their peers and other members of the school community.

Accordingly, this study aimed to impact the challenges mentioned above by engaging middle-grades students (grades 5-8) in a transformational leadership experience through an extracurricular technology leadership club, the Students Working to Advance Technology (SWAT) Team, and examined the following research questions:

1) How does participating in a student-driven technology leadership club impact middle-grade students' affect and school connectedness?

2) How does assistance from a student-driven technology leadership club impact middle-grade teachers' use of educational technology?

\section{LITERATURE REVIEW AND THEORETICAL FRAMEWORK}

\section{Sense of Belonging}

One of the key constructs of students' school connectedness is their sense of belonging (Trujillo \& Tanner, 2014). Researchers suggest that students' sense of belonging is positively associated with their academic achievement (Anderman, 2002), expectancies for school success (Goodenow \& Grady, 1993), and intrinsic interest in school and academic efficacy (Roeser, Midgley, \& Urdan, 1996). Furthermore, students' sense of belonging is negatively associated with dangerous, at-risk behavior such as smoking and drinking (Resnick et al., 1997), and the tendency to be absent from school (Nichols, 2003). This may be due to the understanding that human beings are intrinsically motivated to form and sustain interpersonal bonds, as Baumeister and Leary (1995) establish in their belongingness hypothesis. They maintain that the sense of belonging establishes four truths:

[1] Social bonds should form very easily, without requiring specially conducive circumstances [...] [2] People should generally be at least as reluctant to break social bonds as they are eager to form them in the first place [...] [3] People will devote considerable cognitive processing to interpersonal interactions and relationships [...] [4] Real, potential, or imagined changes in one's belongingness status will produce emotional responses, with positive affect linked to increases in belongingness and negative affect linked to decreases in it. (pp. 501-505).

The four truths established by the belongingness hypothesis suggest that students who join a club or extracurricular activity benefit from simply being a member of the group and experience positive emotional responses as a direct result of their participation in the group. In this current study, both the training and activities provided to the S.W.A.T. Team members intentionally underlined these implications following the four truths and ensure that students feel welcome and form bonds with one another to experience a sense of belonging. 


\section{Technology Integration in Schools}

Many educational leaders argue that, while our intentions are good, the majority of our schools do not yet use technology in a way that benefits student learning (Harris \& Hofer, 2009; Lei \& Zhao, 2007; Sheninger \& Murray, 2017; Valadez \& Durán, 2007; Warschauer, 2012). Meaningful and effective technology integration that enhances student engagement can also vary greatly from teacher to teacher within the same school (Warschauer, Knobel, \& Stone, 2004). The problem of effective technology integration is prevalent even among exemplary technology users.

Ertmer et al (2012) examined a group of teachers with perceived high levels of technology use and found that many barriers to effective technology integration still exist, such as lack of resources, lack of support, technology problems, and pressure from standardized tests. Research suggests that increasing teachers' confidence and positive perception in using technology, through training, professional development, and practice, is one part of the solution (Reinhart, Thomas, \& Toriskie, 2011).

Sheninger and Murray (2017) stress leadership through empowerment, asserting that the best school leaders empower others to lead themselves. Martin (2018) also emphasizes the necessity of empowerment as a guide towards moving schools forward. She explains that people embrace work that allows them to solve important problems that make their life or work more meaningful and impactful. Positive studentteacher interactions also improve students' school connectedness, and contribute to their motivation, academic performance, sense of belonging, and attachment to school (Brewster \& Bowen, 2004). Considering these benefits, a student technology leadership program is a logical solution for schools that are facing the challenges of technology integration (Harper, 2008). Building on this rationale, this study describes the S.W.A.T. Team (i.e., the student technology leadership program) and examines the influence of this program on middle-grades students' school connectedness and their teachers' use and perceptions of educational technologies.

\section{METHODS}

The researchers used a mixed-method, multilevel research triangulation design that consisted of two equal parts: one qualitative and one quantitative (Creswell \& Plano-Clark, 2006). This mixed-methods study took place at a middle school (grades 5-8) with eight student participants and 84 teacher participants. 26 of the teacher participants reported that they received technological support from the S.W.A.T. Team during the 2019-2020 school year.

As members of the S.W.A.T. Team, middle-grades students attended weekly meetings after the school hosted by the researcher. These weekly meetings varied in purpose but were mostly held to train S.W.A.T. Team members in Chromebook and Google Suite (now called Google Workspace) applications. Meetings were also held to provide help and support from S.W.A.T. Team members to other students and teachers.

The first author conducted open-ended, semi-structured interviews that took place towards the end of the school year, after students spent 9-10 months as a S.W.A.T. Team member (Appendix A). Next, teacher participants were asked to electronically complete a survey (Appendix B) which included 26 items to examine their use and perceptions of educational technologies.

All student interview data were recorded, transcribed, and analyzed using Moustakas' (1994) phenomenological method. A team of researchers were then given the interview questions and transcriptions and were asked to meet after coding to compare results and discuss preliminary findings for consistency. Likert-scale responses to teacher surveys were first coded into ordinal variables. Teacher participants were also split into three groups for statistical comparisons with respect to the extent of their interactions with the S.W.A.T. Team members: 1) teachers who did not have any interaction, 2) teachers who had interactions for less than 2 hours, and 3) teachers who had interactions for 2 hours or more. Finally, ordinal data from teacher surveys were analyzed with cross-tabulation, including descriptive statistics, Independent Samples T-Tests, and Pearson Correlations. 


\section{FINDINGS}

After the interviews were transcribed, chunked, sorted, and analyzed according to Moustakas' (1994) phenomenological method of data analysis, three main themes were revealed: 1) enhanced abilities, 2) empowered as leaders, and 3) improved sense of belonging (See Table 1). Out of the eight students who participated in open-ended semi-structured interviews, all students mentioned that learning technology skills through the regular training and activities of the S.W.A.T. Team made them more confident with using educational technology and their schoolwork (i.e., enhanced abilities). The prevalence of this theme demonstrates that the student members of the S.W.A.T. Team did experience growth in their perceived skill level with regard to educational technology.

TABLE 1

QUALITATIVE THEMES EMERGED FROM THE STUDENT INTERVIEWS

\begin{tabular}{|c|c|c|c|c|}
\hline $\begin{array}{l}\text { Themes } \\
\end{array}$ & Definition & Example & 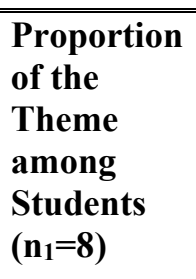 & $\begin{array}{l}\text { Proportion of } \\
\text { the Theme } \\
\text { among } \\
\text { Meaning } \\
\text { Segments } \\
\left(n_{2}=71\right)\end{array}$ \\
\hline $\begin{array}{l}\text { Enhanced } \\
\text { Abilities }\end{array}$ & $\begin{array}{l}\text { The student believes that } \\
\text { technology training as being a } \\
\text { member of a technology team } \\
\text { enhances his/her technology } \\
\text { abilities and helps him/her in } \\
\text { school (Heafner, 2004). }\end{array}$ & $\begin{array}{l}\text { "I learned a lot of things } \\
\text { about the tech skills and } \\
\text { how to do certain things } \\
\text { on the computer that I } \\
\text { wouldn't have learned } \\
\text { otherwise. There have } \\
\text { been more than one times } \\
\text { when we were going to } \\
\text { do something in class and } \\
\text { the teacher is trying to } \\
\text { explain something and } \\
\text { then I'm like, oh we did } \\
\text { this in SWAT team. We } \\
\text { learned how to do this." } \\
\text { (S3) }\end{array}$ & $8(100 \%)$ & $15(21 \%)$ \\
\hline $\begin{array}{l}\text { Empowered } \\
\text { as Leaders }\end{array}$ & $\begin{array}{l}\text { The student considers that } \\
\text { being a member of a } \\
\text { technology team empowers } \\
\text { and motivates him/her as a } \\
\text { leader. The student views the } \\
\text { experiences gained from } \\
\text { being a member of the } \\
\text { technology team helps } \\
\text { him/her to design student-led } \\
\text { projects and assists others to } \\
\text { be able to solve their } \\
\text { problems meaningfully and } \\
\text { impactfully (Martin, 2018). }\end{array}$ & $\begin{array}{l}\text { "One time I helped a } \\
\text { teacher was, um, on } \\
\text { Adobe Spark. They were } \\
\text { having trouble doing } \\
\text { something. So then I went } \\
\text { up to the teacher and I } \\
\text { taught her how to do it. It } \\
\text { made me feel very helpful } \\
\text { and made me feel that I } \\
\text { could help others." (S8) }\end{array}$ & $7(88 \%)$ & $29(41 \%)$ \\
\hline
\end{tabular}




\begin{tabular}{llll}
\hline $\begin{array}{l}\text { Improved } \\
\text { Sense of }\end{array}$ & The student experiences & "[...] just meeting, coming & $8(100 \%)$ \\
enhanced feelings of & together with a bunch of & $31(44 \%)$ \\
belonging & belongingness, attachment to & other people who have the \\
& school, and strong social & same kind of interests, \\
bonds through their & and talking and joking \\
& membership in the club & and working together $[\ldots]$ \\
& (Knifsend \& Graham, 2012). & like the unity." (S7)
\end{tabular}

Sense of belonging was the dominant theme that emerged from the interview data, for all students interviewed. These qualitative findings strongly suggest that the student participants care deeply about having a social group that makes them feel accepted in school. For these students, the S.W.A.T. Team was primarily a social event where they could meet people and make new friends. The high frequency of this theme in the transcripts suggests that it was of the utmost importance to them compared to the other themes and that other middle-grades students would likely have similar sentiments.

To determine if teachers' perceptions towards the use of technology in education influenced their degree of interaction with the S.W.A.T. Team members in a statistically significant way, Independent Samples T-Tests were performed. Table 2 shows that responses to statements 3a-c did not have a statistically significant difference between the teachers who did have interactions with the S.W.A.T. Team members and those who did not. Although the findings were not statistically significant, the slight differences in the mean values indicate that teachers who interacted with the S.W.A.T. Team members had slightly more favorable responses to all three statements than teachers who did not interact with the S.W.A.T. Team members.

TABLE 2

TEACHERS' PERCEPTIONS OF EDUCATIONAL TECHNOLOGY

\begin{tabular}{llll}
\hline Survey Item Number & $\begin{array}{l}\text { Mean (Standard } \\
\text { Deviation) for Teachers } \\
\text { having no interaction } \\
\text { with the SWAT Team } \\
\text { members } \\
\left(\mathbf{n}_{\mathbf{1}}=\mathbf{5 8}\right)\end{array}$ & $\begin{array}{l}\text { Mean (Standard } \\
\text { Deviation) for } \\
\text { Teachers having } \\
\text { some interaction } \\
\text { with the SWAT } \\
\text { Team members } \\
\left(\mathbf{n}_{\mathbf{2}}=\mathbf{2 6}\right)\end{array}$ & $\begin{array}{l}\text { Independent } \\
\text { Samples T-Test } \\
\text { Comparisons }(\boldsymbol{T} \\
\text { and } \boldsymbol{p} \text {-values) }\end{array}$ \\
\hline $3 a$ & $3.55(0.65)$ & $3.58(0.70)$ & $\begin{array}{l}\mathrm{t}=-0.160 \\
(p=0.874)\end{array}$ \\
$3 b$ & $3.43(0.62)$ & $3.50(0.71)$ & $\begin{array}{l}\mathrm{t}=-0.449 \\
(p=0.655)\end{array}$ \\
$3 c$ & $3.45(0.68)$ & $3.46(0.71)$ & $\begin{array}{l}\mathrm{t}=-0.082 \\
(p=0.935)\end{array}$ \\
\hline
\end{tabular}

Table 3 summarizes the responses to various Likert-scale items that asked teachers, who interacted with the S.W.A.T. Team members, to reflect upon the changes in their perceived use of technology. The most favorable response was to the following statement: "Your students use technology to complete assignments," to which $69 \%$ of teachers and staff replied more frequently. These findings suggest that, while the impact on changes in teacher technology use was minimal, there was a profound impact on student 
technology use since the most favorable response (i.e., "your students use technology to complete assignments") focuses on student technology use.

TABLE 3

PERCEIVED USE OF TECHNOLOGY FOR TEACHERS WHO INTERACTED WITH S.W.A.T. TEAM MEMBERS

\begin{tabular}{lllll}
\hline \hline Survey Item Number & \multicolumn{3}{c}{ Proportion of the Responses } \\
& More Frequently & Stayed the Same & Less Frequently & $N / A$ \\
\hline $5 \mathrm{a}$ & $10(38 \%)$ & $14(54 \%)$ & $0(0 \%)$ & $2(8 \%)$ \\
$5 \mathrm{~b}$ & $11(42 \%)$ & $12(46 \%)$ & $0(0 \%)$ & $3(11 \%)$ \\
$5 \mathrm{c}$ & $10(38 \%)$ & $14(54 \%)$ & $0(0 \%)$ & $2(8 \%)$ \\
$5 \mathrm{~d}$ & $7(27 \%)$ & $15(58 \%)$ & $1(4 \%)$ & $3(11 \%)$ \\
$5 \mathrm{e}$ & $8(31 \%)$ & $14(54 \%)$ & $1(4 \%)$ & $3(11 \%)$ \\
$5 \mathrm{f}$ & $18(69 \%)$ & $6(23 \%)$ & $0(0 \%)$ & $2(8 \%)$ \\
\hline
\end{tabular}

To determine if the amount of time spent working with student members of the S.W.A.T. Team had a statistically significant effect on teachers' perception and comfort level of using educational technologies, Independent Samples T-Tests were performed for a second time. It was found that the degree of interaction that teachers had with student members of the S.W.A.T. Team did have a statistically significant effect on teachers' use of technology to prepare for class or to maintain class records (i.e., survey item 5a), $\mathrm{t}=$ $2.184 ; \mathrm{p}=0.046$. The data also revealed that the degree of interaction that teachers had with S.W.A.T. Team members did have a statistically significant effect on teachers' use of educational technology sites or apps while teaching (i.e., survey item $5 b$ ),$t=-2.993 ; p=0.008$. Finally, data analysis indicated a statistically significant correlation between the time teachers spent working with the SWAT Team members and the change in the perceived comfort level of using technology for lessons and curriculum as a result of working with the SWAT Team (i.e., survey item $6 \mathrm{~b}$ ), $r=.469, \mathrm{n}=26, p=0.016$.

\section{CONCLUSION}

\section{Significance of the Study}

The results suggest that student technology leadership clubs are an outstanding way to provide social connections and attachment to school for students that are not likely to fit in with other social circles. Once the club is established, it should be mostly student-led. At the very least, students should be afforded the opportunity to use their unique perspectives to provide insight into the strengths and weaknesses of the school's technology program. Rigorous technology training is essential to provide students with the skills and confidence necessary to make a bigger impact on technology usage around the school.

The results for the second research question show that student technology leadership clubs make an impact beyond the allotted time and physical space of the regular meetings. In the open-ended items on the survey, many teachers explained detailed encounters of S.W.A.T. Team members stepping up to help in class during regular instructional activities, when help is often needed most. Teacher training and technology support are often best when they are ongoing, job-embedded, and within a teacher's classroom 
(Hooker, 2016; Sugar, 2005). Accordingly, future implementation of the S.W.A.T. Team will focus on providing ongoing support to teachers for their regular instructional activities within their classrooms.

\section{Implications}

While student technology leadership clubs can provide much-needed support for school technology programs, we cannot lose sight of our true goals as educators: to empower students and give them the academic, social, and emotional skills these individuals need to be successful in their own lives. The student technology leadership program presented in this mixed-methods study was able to provide a solution to the problems that educators face with school technology, however; technology was just the medium that provided the opportunity for change. In the end, it mostly served to produce the conditions that enabled us to make a bigger impact in the lives of the students themselves.

Student affect and attachment to school are far too important to overlook. No pedagogical decision should ever be made without strong consideration of these factors. Luckily, any improvement in these areas is likely to induce a ripple effect of positive change in the school. The intervention measured in this study embraced the core concepts of student affect and school connectedness, while simultaneously addressing another common problem - the problem of educational technology. As technology continues to evolve and we move further into the 21 st century, more and more new and unique opportunities to connect students to their school communities will come about. School leaders should take a good hard look at their extracurricular offerings and ensure that there are ample, diverse options for students and that we continue to adjust these offerings with the ever-changing educational, social, and technological landscape our students experience every day.

The timely relevance of this study, occurring during the school closures resulting from the coronavirus pandemic, was a profound coincidence. Teachers worldwide were forced into emergency remote learning and educational technology became an absolute necessity. We now realize, even more so than before, the awesome potential of educational technology; however, even schools with robust technology programs with strong, built-in support systems have their struggles. As technology changes ever so rapidly, so do the needs of teachers and students who use those technologies. There is no debate that support for educational technology programs must improve, and there is little time to waste. Student technology leadership programs provide a proven solution that is convenient, affordable, and beneficial to all involved. Most importantly, such programs are proven to make an impact on the hearts and minds of our students.

\section{ACKNOWLEDGEMENTS}

I would like to express sincere thanks to my dissertation chair and co-researcher Dr. Vecihi S. Zambak, as well as my committee members Dr. Raj and Dr. Greason for their guidance, expertise, and support. I am grateful to my administrators, staff, and school community in Ocean Township for supporting my project. Most importantly, I'd like to thank my S.W.A.T. Team students, who made this project possible.

\section{REFERENCES}

Anderman, E.M. (2002). School effects on psychological outcomes during adolescence. Journal of Educational Psychology, 94(4), 795.

Baumeister, R.F., \& Leary, M.R. (1995). The need to belong: Desire for interpersonal attachments as a fundamental human motivation. Psychological Bulletin, 117(3), 497.

Brewster, A.B., \& Bowen, G.L. (2004). Teacher support and the school engagement of Latino middle and high school students at risk of school failure. Child and Adolescent Social Work Journal, 21(1), 47-67.

Creswell, J.W., \& Plano-Clark, V.L. (2006). Choosing a mixed methods design. In Designing and conducting mixed methods research (pp. 58-88). Thousand Oaks: SAGE Publications.

Dolan, J.E. (2016). Splicing the divide: A review of research on the evolving digital divide among K-12 students. Journal of Research on Technology in Education, 48(1), 16-37. 
Ertmer, P.A., \& Hruskocy, C. (1999). Impacts of a university-elementary school partnership designed to support technology integration. Educational Technology Research and Development, 47(1), 8196.

Ertmer, P.A., Ottenbreit-Leftwich, A.T., Sadik, O., Sendurur, E., \& Sendurur, P. (2012). Teacher beliefs and technology integration practices: A critical relationship. Computers \& Education, 59(2), 423435.

Goodenow, C., \& Grady, K.E. (1993). The relationship of school belonging and friends' values to academic motivation among urban adolescent students. The Journal of Experimental Education, 62(1), 60-71

Harper, D. (2008). Vision to action: Adding student leadership to your technology plan. Generation Yes. Retrieved from http://genyes.org/media/programs/how_to_include_students_in_tech_plan.pdf

Harris, J., \& Hofer, M.J. (2009). Grounded tech integration: An effective approach based on content, pedagogy, and teacher planning. Learning \& Leading With Technology, 37(2), 22-25.

Heafner, T. (2004). Using technology to motivate students to learn social studies. Contemporary Issues in Technology and Teacher Education, 4(1), 42-53.

Henrie, C.R., Halverson, L.R., \& Graham, C.R. (2015). Measuring student engagement in technologymediated learning: A review. Computers \& Education, 90, 36-53.

Hooker, C. (2016). Mobile learning mindset: The coach's guide to implementation. Portland, OR: International Society for Technology in Education.

Hudson, D.J., \& Lowrey, K. (2016). On dark continents and digital divides: Information inequality and the reproduction of racial otherness in library and information studies. Journal of Information Ethics, 25(1), 62.

Klem, A.M., \& Connell, J.P. (2004). Relationships matter: Linking teacher support to student engagement and achievement. Journal of School Health, 74(7), 262-273.

Knifsend, C.A., \& Graham, S. (2012). Too much of a good thing? How breadth of extracurricular participation relates to school-related affect and academic outcomes during adolescence. Journal of Youth and Adolescence, 41(3), 379-389.

Lei, J., \& Zhao, Y. (2007). Technology uses and student achievement: A longitudinal study. Computers \& Education, 49(2), 284-296.

Martin, K. (2018). Learner-centered innovation: Spark curiosity, ignite passion, and unleash genius. San Diego, CA: IMpress.

Morris, R.C., \& Parker, L.C. (2014). Examining the connection between classroom technology and student engagement. Journal of Teaching and Learning With Technology, 3(1), 1-15.

Moustakas, C. (1994). Phenomenological research methods. Thousand Oaks, CA: Sage Publications, Inc.

Nichols, S.L. (2003). The role of belongingness in middle school students' motivational adaptation to a new school setting: Do fresh starts make a difference? Unpublished doctoral dissertation, University of Arizona, Tucson.

Reinhart, J.M., Thomas, E., \& Toriskie, J.M. (2011). K-12 teachers: Technology use and the second level digital divide. Journal of Instructional Psychology, 38(3/4), 181-193.

Resnick, M.D., Bearman, P.S., Blum, R.W., Bauman, K.E., Harris, K.M., Jones, J., ,. Udry, J.R. (1997). Protecting adolescents from harm: Findings from the National Longitudinal Study on Adolescent Health. Journal of the American Medical Association, 278, 823-832.

Roeser, R.W., Midgley, C., \& Urdan, T.C. (1996). Perceptions of the school psychological environment and early adolescents' psychological and behavioral functioning in school: The mediating role of goals and belonging. Journal of Educational Psychology, 88, 408-422.

Sheninger, E., \& Murray, T. (2017). Learning transformed: 8 Keys to designing tomorrow's schools, today. Alexandria, VA: ASCD.

Sugar, W. (2005). Instructional technologist as a coach: Impact of a situated professional development program on teachers' technology use. Journal of Technology and Teacher Education, 13(4), 547571. 
Trujillo, G., \& Tanner, K.D. (2014). Considering the role of affect in learning: Monitoring students' selfefficacy, sense of belonging, and science identity. CBE-Life Sciences Education, 13(1), 6-15.

Wang, M.T., \& Holcombe, R. (2010). Adolescents' perceptions of school environment, engagement, and academic achievement in middle school. American Educational Research Journal, 47(3), 633662.

Warschauer, M. (2012). The digital divide and social inclusion. Americas Quarterly, 6(2), 131-135.

Warschauer, M., Knobel, M., \& Stone, L. (2004). Technology and equity in schooling: Deconstructing the digital divide. Educational Policy, 18(4), 562-588.

\section{APPENDIX A: STUDENT INTERVIEW PROTOCOL}

1. How long have you attended our Intermediate School?

2. Are you currently, or have you in the past, been involved with any other extracurricular activity or club before? If so, please describe it.

3. How confident are you about the use of technology?

4. How confident are you about helping other students or teachers with technology?

5. Have you taken any technology courses in this school or in elementary school? If so, what were they?

6. What were your experiences with technology before joining the SWAT Team?

7. Why did you decide to join the SWAT Team?

8. Describe what you did as a member of the SWAT Team.

9. What did you like about the SWAT Team? What did you dislike about it?

10. What have you learned through your participation in the SWAT Team?

11. What are your favorite memories of the SWAT Team?

12. Can you think of a time when you helped a student? If so, how did that make you feel?

13. Can you think of a time when you helped a teacher? If so, how did that make you feel?

14. Did you work hard as a member of the SWAT Team? If so, what encouraged you to work hard?

15. What did you like about the SWAT Team that motivated you to attend regularly?

16. Do you generally enjoy coming to school? If not, did being a member of the SWAT Team change how you feel about coming to school?

17. Do you usually do well in school? Why or why not?

18. Do you think that being a member of the SWAT Team helped you perform better in school?

19. Do you usually like school? Why or why not?

20. Do you think that being a member of the SWAT Team changed the way you feel about school?

21. Will you participate in the SWAT Team in the future? Why or why not?

\section{APPENDIX B: TEACHER TECHNOLOGY SURVEY}

\section{Basic Information}

1. How many years of experience do you have working in education? (Round to a whole number of years)
a) Less than 5 years
c) 11-15 years
d) 16-20 years
f) 26-30 years
b) 5-10 years
e) 21-25 years
g) 31-35 years
h) More than 35 years

2. Please choose the primary subject that you teach:
a) Math
b) Science
d) Social
studies
c) English
e) World
languages
f) Special education
g) Basic skills language arts 

h) Health and physical education
i) Technology
j) Music and
arts
k) Various subjects
1) Other:

3. Please rate your opinions regarding the use of technology in education:

\begin{tabular}{|l|l|l|l|l|}
\hline & $\begin{array}{l}\text { Strongly } \\
\text { Agree }\end{array}$ & Agree & Disagree & $\begin{array}{l}\text { Strongly } \\
\text { Disagree }\end{array}$ \\
\hline a) I see definite benefits to students from & & & & \\
integrating technology into education & & & & \\
\hline b) $\begin{array}{l}\text { Technology enables positive changes to } \\
\text { traditional classroom teaching and learning } \\
\text { practices }\end{array}$ & & & & \\
\hline c) & $\begin{array}{l}\text { c) I want to learn more about using new } \\
\text { educational technologies }\end{array}$ & & & \\
\hline
\end{tabular}

4. About how much time, in total, did you spend working with student members of the SWAT Team this year on technology-related issues? (Include any time the SWAT Team members provided support for you or your students, either remotely or in-person)
a) None
d) 6-8 hours
b) 2 hours or less
e) 9 hour or more
c) 3-5 hours

5. How has the frequency of the following changed as a result of your involvement with the students in the SWAT Team?

\begin{tabular}{|c|c|c|c|c|}
\hline & $\begin{array}{l}\text { More } \\
\text { Frequently }\end{array}$ & $\begin{array}{l}\text { Stayed } \\
\text { the Same }\end{array}$ & $\begin{array}{l}\text { Less } \\
\text { Frequently }\end{array}$ & N/A \\
\hline $\begin{array}{l}\text { a) You use technology to prepare for class } \\
\text { or to maintain class records }\end{array}$ & & & & \\
\hline $\begin{array}{l}\text { b) You use educational technology sites or } \\
\text { apps while teaching }\end{array}$ & & & & \\
\hline $\begin{array}{l}\text { c) You use technology for personal business, } \\
\text { learning, and fun }\end{array}$ & & & & \\
\hline $\begin{array}{l}\text { d) You use hardware, such as interactive } \\
\text { white boards or document cameras, in the } \\
\text { classroom }\end{array}$ & & & & \\
\hline $\begin{array}{l}\text { e) You use technology to help with a } \\
\text { student's modifications (i.e., IEP or 504) }\end{array}$ & & & & \\
\hline $\begin{array}{l}\text { f) Your students use technology to complete } \\
\text { assignments }\end{array}$ & & & & \\
\hline
\end{tabular}

6. How has your comfort level with the following changed as a result of your involvement with the students in the SWAT Team? 


\begin{tabular}{|c|c|c|c|c|}
\hline & $\begin{array}{l}\text { More } \\
\text { Comfortable }\end{array}$ & $\begin{array}{l}\text { Stayed } \\
\text { the Same }\end{array}$ & $\begin{array}{l}\text { Less } \\
\text { Comfortable }\end{array}$ & $\mathrm{N} / \mathrm{A}$ \\
\hline a) Using technology for personal use & & & & \\
\hline $\begin{array}{l}\text { b) Integrating technology into lessons/the } \\
\text { curriculum }\end{array}$ & & & & \\
\hline c) Helping students with technology & & & & \\
\hline d) Exploring new educational technologies & & & & \\
\hline e) Collaborating with other teachers & & & & \\
\hline $\begin{array}{l}\text { f) Assigning work or projects that involve } \\
\text { technology }\end{array}$ & & & & \\
\hline
\end{tabular}

7. Is there anything else that changed as a result of your involvement with the students in the SWAT Team? If so, please explain:

8. Please indicate your level of agreement with each of the following:

\begin{tabular}{|c|c|c|c|c|c|}
\hline & $\begin{array}{l}\text { Strongly } \\
\text { Agree }\end{array}$ & Agree & Disagree & $\begin{array}{l}\text { Strongly } \\
\text { Disagree }\end{array}$ & N/A \\
\hline $\begin{array}{l}\text { a) I would like the opportunity to work } \\
\text { with SWAT Team students in the } \\
\text { future. }\end{array}$ & & & & & \\
\hline $\begin{array}{l}\text { b) Collaborating with SWAT Team } \\
\text { students was relatively easy. }\end{array}$ & & & & & \\
\hline $\begin{array}{l}\text { c) As a consequence of the SWAT Team, } \\
\text { I learned more about technology. }\end{array}$ & & & & & \\
\hline $\begin{array}{l}\text { d) As a consequence of the SWAT Team, } \\
\text { my students learned more about } \\
\text { technology (either directly or } \\
\text { indirectly). }\end{array}$ & & & & & \\
\hline $\begin{array}{l}\text { e) As a consequence of the SWAT Team, } \\
\text { my students learned more about some } \\
\text { content area. }\end{array}$ & & & & & \\
\hline $\begin{array}{l}\text { f) The SWAT Team is a good method for } \\
\text { providing support and assistance to } \\
\text { teachers. }\end{array}$ & & & & & \\
\hline $\begin{array}{l}\text { g) The SWAT Team is a good method for } \\
\text { providing support and assistance to } \\
\text { students. }\end{array}$ & & & & & \\
\hline $\begin{array}{l}\text { h) My experience with the SWAT Team } \\
\text { this year will change the way I teach in } \\
\text { the future. }\end{array}$ & & & & & \\
\hline $\begin{array}{l}\text { i) I would like to work with another } \\
\text { SWAT Team student in the coming } \\
\text { year. }\end{array}$ & & & & & \\
\hline $\begin{array}{l}\text { j) I have seen positive social changes in } \\
\text { my students who are members of the } \\
\text { SWAT Team. }\end{array}$ & & & & & \\
\hline
\end{tabular}

9. Could you explain things you liked about working with students in the SWAT Team?

10. Could you explain things you did not like about working with students in the SWAT Team? 